\title{
Research Note
}

\section{IDENTITY AND ECONOMIC IMPORTANCE OF FRUIT FLIES ATTACKING MANGO IN PUERTO RICO: A TWO-YEAR SURVEY' ${ }^{\prime}$.}

Recently, an old controversy has surfaced concerning the number of fruit fly species of the genus Anastrepha Schiner attacking mango (Mangifera indica L.) in Puerto Rico. At present, only two economically important species occur in Puerto Rico: $A$. obliqua (Macquart) and $A$. suspensa (Loew), both of which have been studied here in detail since the beginning of this century. ${ }^{2,4,5}$ Resident entomologists working on he subject have found no species other than $A$. obliqua attacking mangoes ${ }^{2,4,5}$ in Puerto Rico. Meanwhile, regulatory agencies have insisted on the possibility that both species may occur in mango. Their insistence is based on conjecture ${ }^{3}$ and $\mathrm{ex}$ trapolation from data obtained elsewhere. Three major factors have historically contributed to fuel the present controversy: 1) the presence of adults, particularly $A$. suspensa in mango groves $\left.{ }^{4} ; 2\right)$ the finding in the state of Florida of $A$. suspensa feeding on mangoes; and 3) the lack of an intensive study specifically designed to identify fruit fly species using mango as a host in Puerto Rico.

To address this problem a total of 22,323 mangoes belonging to 27 varieties were sampled during the 1986 and 1987 harvest season. Only mature-green or ripe fruits were surveyed. Fruits were placed inside wire baskets over moist sand trays. Larvae and pupae were colected from trays every $3-4$ days and placed in plastic cups with moist vermiculite ( 80 vermiculite: 20 water w/w). Adults were identified upon emergence.

A total of 5,491 larvae were obtained from this survey. All emerging adults were unequivocally identified as $A$. obliqua. No specimen of $A$. suspensa was ever recorded from the 22,323 mangoes sampled to date. This result confirms the findings of past resident entomologists, ${ }^{2,4,5}$ and strongly indicates that $A$. suspensa does not attack mango in Puerto Rico.

Most larvae (66.5\%) were recovered from local varieties like: Mayagüezano, Rosita and Cubano. Infestation rate in these mangoes was highest with 1,560 larvae per thousand mangoes.

On the other hand, the commercially important varieties Keitt, Irwin, Parvin, Palmer and Haden, had an average infesta. tion rate of 27 larvae per thousand mangoes. This low infestation rate is responsible for the general lack of concern by the farmers about this fruit fly.

Alejandro E. Segarra

Department of Crop Protection

${ }^{1}$ Manuscript submitted to Editorial Board 2 January 1988.

${ }^{2}$ Hooker, C. W., 1913. Report of the entomologist. Annu. Rep. P. R. Agric. Exp. Stn. 1912: $34-6$.

${ }^{3}$ Marlatt, C. L., 1925. In: Public hearing to consider the advisability of restricting or prohibiting the entry from Puerto Rico of fruits and vegetables in the raw or unmanufactured state on account of the West Indian fruit fly, the bean pod borer and other injurious insects. Report. J. Agric. Dep. P. R. 8: 5-46.

${ }^{4} \mathrm{McAlister}, \mathrm{L}$. C., 1941. A study of the adult populations of the West Indian fruit fly in citrus plantings in Puerto Rico. USDA-P. Exp. Stn. Bull. 41. Mayagüez, P. R.

${ }^{5}$ Seín, F., 1933. Anastrepha (Trypetidae, Diptera) fruit flies in Puerto Rico. J. Agric. Univ. P. R. 17: 183-96.

${ }^{6}$ von Windeguth, D., W. H. Price and L. F. Steiner, 1973. Infestations of Anastrepha suspensa in fruit on Key West, Florida and adjacent islands. Fla. Entomol, 56: 127-31. 